\title{
PERBANDINGAN KEBOCORAN MIKRO PADA RESTORASI RESIN KOMPOSIT MIKROFILLER DENGAN RESIN-MODIFIED GLASS IONOMER CEMENT (RMGIC) PADA KAVITAS KLAS V GIGI ANTERIOR Thesi Kurnia Ayudia ${ }^{1}$, Kuswardani Susari Putri ${ }^{2}$, Ivony Fitria ${ }^{3}$ \\ ${ }^{1}$ Mahasiswa Fakultas Kedokteran Gigi Universitas Andalas \\ ${ }^{2}$ Staf Pengajar Fakultas Kedokteran Universitas Andalas \\ ${ }^{3}$ Staf Pengajar Fakultas Kedokteran Gigi Universitas Andalas
}

\section{ABSTRACT}

Microleakage defined as the clinically undetectable passage of bacteria, fluids, molecules or ions between a cavity wall and the restorative material. Microleakage tends to occur in Class V cavities. It is caused by marginal adaptation which is more difficult in class $V$ cavities. Microfiller composite resin is developed and indicated for areas that not require a large pressure. As the development of dental materials, it has been developed a composite resin base material that is known as resin-modified glass ionomer cement. This material has purposed to reduce the limitation of conventional glass ionomer cement and take the advantage of the composite resin material.

The aim of this study was to evaluate microleakage difference of microfiler composite resin restoration with resin-modified glass ionomer cement restorations in class $V$ anterior teeth cavities. The methode of this study used experimental laboratory through in vitro process. Thirty two class $V$ cavities were prepared on labial surfaces of extracted human anterior teeth. Samples were divided into two groups. Group I included sixteen samples that have had restorated with microfiller composite. Group II included sixteen samples that have had restorated with resin-modified glass ionomer cement. The samples were immersed into aquabides solution for 24 hours. After that, the samples were immersed into $1 \%$ methylene blue solution for 24 hours. All samples sectioned longitudinally and analyzed for microleakage as dye penetration using a stereomicroscope.

Student t-test were used for statistical analysis. The resulting data showed no significantly difference between two groups.

Key Word : Microleakage, microfiller composite resin, resin-modified glass ionomer cement (RMGIC), class $V$ cavities.

Affiliasi penulis : 1. Fakultas Kedokteran Gigi Universitas Andalas

Korespondensi : Thesi Kurnia Ayudia, e-mail : thesy_ayudiamail@yahoo.com

\section{PENDAHULUAN}

Kehadiran bahan restorasi sewarna gigi merupakan suatu hal yang paralel dengan sejarah kedokteran gigi. Bahan restorasi untuk gigi anterior hendaknya bersifat adhesif, warna sesuai dengan gigi yang ada, dapat diterima gigi dan jaringan lunak, mudah dikerjakan serta dapat mengembalikan bentuk dan fungsi gigi. ${ }^{1}$

Resin komposit digunakan untuk menggantikan struktur gigi yang hilang dan memodifikasi warna dan kontur gigi sehingga mempertinggi estetik di facial. Sejumlah resin komposit tersedia untuk berbagai aplikasi. Beberapa resin komposit digunakan untuk mengoptimalkan kebutuhan estetis dan ada yang dirancang untuk area yang 
berhubungan dengan tekanan yang besar. Resin sintetik berkembang sebagai bahan tambal atau restorasi karena sifatnya yang tidak mudah larut, estetis, tidak peka terhadap dehidrasi, tidak mahal, dan relatif mudah untuk dimanipulasi. Meskipun demikian bahan tersebut hanya dapat memenuhi sebagai persyaratan dari bahan restorasi yang estetis dan tahan lama untuk gigi anterior. $^{2,3}$

Sejumlah sistem klasifikasi telah digunakan untuk bahan komposit berbasis resin. Suatu sistem klasifikasi didasarkan pada ukuran rata-rata partikel utama. Klasifikasi komposit berbasis resin yaitu komposit tradisional, komposit barbahan pengisi partikel kecil, komposit berbahan pengisi mikro, dan komposit hibrid. ${ }^{3}$

Resin komposit mikrofiller diindikasikan untuk restorasi kelas III dan V dimana sangat membutuhkan permukaan poles dan estetik yang tinggi. Namun, dalam keadaan yang memerlukan ketahanan terhadap tekanan, seperti kelas I, II dan IV kemungkinan pecahnya restorasi lebih besar. Bagaimanapun juga, komposit berbahan pengisi mikro banyak digunakan dewasa ini. Karena permukaannya halus, bahan ini menjadi resin pilihan untuk merestorasi estetika gigi anterior, khususnya untuk daerah yang tidak perlu menahan beban, dan untuk menambal daerah subgingival. ${ }^{2,3}$

Resin komposit sangat banyak digunakan pada lesi servikal karena memiliki estetik yang sangat baik, terbebas dari merkuri dan terikat dengan struktur gigi dengan adanya sistem bonding. Restorasi pada lesi servikal dengan resin komposit selalu menimbulkan masalah, terutama karena tidak adanya enamel yang mengikat pada daerah margin gingival. Kaplan, et al dalam penelitiannya mengatakan adaptasi marginal lebih sulit pada kavitas klas V karena sedikit atau tidak ada enamel pada margin servikal dan bahan berkontak dengan sementum sehingga menyebabkan penurunan adhesi serta memfasilitasi terlepasnya bahan. ${ }^{4,5}$

Perlekatan dengan dentin lebih susah dibandingkan dengan enamel, dentin bonding agent digunakan untuk memperbaiki penutupan tepi dari restorasi resin komposit/penghubung gigi tapi hanya efektif untuk menurunkan tetapi tidak mengeliminasi kebocoran mikro. ${ }^{4}$

Kebocoran mikro didefinisikan sebagai sebuah pergerakan yang tidak terdeteksi secara klinis dari cairan 
bakteri, molekul dan ion-ion pada celah mikro $(10-6 \mu)$ diantara dinding kavitas dan tumpatan bahan restorasi. Faktor yang menyebabkan terbentuknya celah tepi dan kebocoran diantara dinding kavitas dan bahan restorasi meliputi adhesi yang buruk, temperatur yang berubah-ubah, kekuatan kontraksi, penyusutan saat polimerisasi, kontrol kelembaban yang tidak adekuat dan tekanan otot-otot mastikasi. ${ }^{4}$

Celah mikro yang terbentuk pada margin dapat mempercepat masuknya bakteri yang sensitif setelah penempatan karena terjadinya fenomena hidrodinamika interfasial. Celah mikro juga akan menyebabkan pewarnaan, restorasi yang rusak, karies sekunder, dan kemungkinan pathosis pulpa. ${ }^{4}$

Untuk mengurangi keterbatasan dan memanfaatkan keuntungan dari bahan restorasi glass ionomer cement konvensional serta memanfaatkan keuntungan dari material resin komposit maka telah dikembangkan suatu bahan yaitu Resinmodified glass ionomer cement. Dari hasil laporan klinis bahan ini telah digunakan untuk aplikasi-aplikasi tertentu, seperti untuk restorasi kavitas klas V di sepanjang garis gusi yang digunakan untuk gigi anterior. Hal ini memperlihatkan bahan ini sangat cocok dan memberikan hasil yang sangat baik. ${ }^{6,7}$

Resin-modified glass ionomer cement merupakan semen ionomer kaca yang mengandung resin sehingga dapat dipolimerisasi dengan aktivasi sinar. Komponen ini mampu meningkatkan estetik awal, meningkatkan sifat fisik (seperti tensile strength dan fracture toughness), reaksi pengerasan dilakukan dengan light curing serta mudah dalam penggunaannya. Namun Reaksi polimerimerisasi pada resin- modified glass ionomer cement menyebabkan terjadinya shrinkage selama proses setting berlangsung. Kandungan air dan carbocylix acid yang rendah juga menurunkan kemampuan semen untuk membasahi substrat gigi sehingga akan meningkatkan terjadinya kebocoran mikro. $^{8}$

Berdasarkan uraian diatas dapat diketahui bahwa penggunaan resin komposit mikrofiller dan resin-modified glass ionomer diindikasikan untuk penambalan gigi anterior dan baik digunakan pada kavitas klas $\mathrm{V}$ namun belum ada penelitian mengenai perbedaan kebocoran mikro pada kedua bahan tersebut. Untuk itu peneliti akan melakukan penelitian mengenai evaluasi perbandingan kebocoran mikro pada restorasi resin komposit mikrofiller 
dengan resin- modified glass ionomer cement pada kavitas klas $\mathrm{V}$ gigi anterior.

\section{MATERI DAN METODE}

Penelitian ini bertujuan untuk mengetahui perbedaan kebocoran mikro pada restorasi resin komposit mikrofiler dengan resin-modified glass ionomer cement pada kavitas klas $\mathrm{V}$ gigi anterior. Penelitian ini merupakan penelitian yang bersifat eksperimental laboratorik yang dilakukan di Fakultas Kedokteran Gigi Universitas Andalas Padang dan Laboratorium Metalurgi jurusan teknik mesin Fakultas Teknik Universitas Andalas pada bulan Februari 2015. Sampel pada penelitian ini adalah Preparat gigi anterior yang telah direstorasi klas $\mathrm{V}$ dengan ukuran 3 $\mathrm{mm} \quad \mathrm{x} \quad 2 \mathrm{mmx} 2 \mathrm{~mm}$ dengan menggunakan bahan restorasi resin komposit mikrofiller sebanyak 16 sampel dan resin-modified glass ionomer cement sebanyak 16 sampel.

Alat yang digunakan dalam penelitian ini adalah mikromotor, bur diamond, Stereomicroscope, Sonde, Semen spatel, Light- cure woodpecker, Eskavator, Inkubator, Chip Blower, Sliding caliper, Robber bowl, spatula, Pinset, Handscoon dan masker. Bahan yang digunakan dalam penelitian ini adalah preparat gigi anterior, Cat kuku,
Resin komposit mikrofiller merek 3M, Resin-modified glass ionomer cement merek Shofu, Gips stone, Larutan pewarna $1 \%$ methylene blue, Pipa, Aluminium foil, Resin akrilik autopolimerisasi, Aquabides, Bonding agent dan etching bermerek $3 \mathrm{M}$.

Sebanyak 32 gigi dipreparasi kavitas klas $\mathrm{V}$ dengan ukuran $3 \mathrm{~mm} \mathrm{x}$ $2 \mathrm{~mm} \times 2 \mathrm{~mm}$. Kemudian ditambal dengan resin komposit mikrofiler sebanyak 16 sampel dan resin-modified glass ionomer cement sebanyak 16 sampel. Semua specimen direndam dengan aquabides dan disimpan dalam incubator bersuhu $37^{\circ} \mathrm{C}$ selama 24 jam. Sampel kemudian dilapisi dengan cat kuku sebanyak 2 lapis dan 4 lapis pada ujung akar, kecuali $2 \mathrm{~mm}$ dari tepi restorasi. Apeks ditutup dengan resin akrilik autopolimerisasi.

Sampel direndam dalam methylene blue 1\% selama 24 jam. Kemudian diangkat dan dibersihkan. Gigi ditanam dalam pipa dengan ukuran $3 \mathrm{~cm}$. setiap gigi dibelah dalam arah labiolingual kemudian diperiksa dibawah stereomicroscope.

Data hasil penelitian kemudian dianalisis secara statistic dengan menggunakan uji-t. 


\section{HASIL PENELITIAN}

Hasil penelitian dilakukan uji normalitas data terlebih dahulu dengan menggunakan Test of Normality Shapiro Wilk. Hasil uji Shapiro Wilk didapatkan kebocoran mikro pada grup I dengan nilai $\mathrm{p}=0,055$ dan pada grup II dengan nilai $\mathrm{p}=0,083$. Pada grup I dan grup II didapatkan nilai $\mathrm{p}>0,05$, maka kedua data berdistribusi normal. Karena data terdistribusi normal dapat dilakukan uji hipotesis dengan menggunakan independent t-test.

Tabel 5.1 Hasil uji-t antara kebocoran mikro pada restorasi resin komposit mikrofiler dengan resin-modiffied glas ionomer cement pada kavitas klas V gigi anterior.

\begin{tabular}{llll}
\hline Grup & $\mathrm{n}$ & Rerata \pm s.d & $\mathrm{p}$ \\
\hline I & 16 & $1348.87 \pm 580.52$ & 0.280 \\
II & 16 & $993.62 \pm 635.44$ & \\
\hline
\end{tabular}

Dari tabel 5.1 diatas, dapat dilihat bahwa rerata kebocoran mikro pada grup I adalah $1348.87 \mu \mathrm{m}$ dan grup II adalah $993.62 \mu \mathrm{m}$ dengan nilai $\mathrm{p}>0,05$ yaitu 0,280. Maka dapat disimpulkan bahwa tidak ada perbedaan yang signifikan antara kebocoran mikro pada restorasi resin komposit mikrofiller dengan resin-modified glass ionomer cement pada kavitas klas $\mathrm{V}$ gigi anterior.

\section{PEMBAHASAN}

Pada penelitian ini dilakukan evaluasi kebocoran mikro pada dua jenis bahan tambal yaitu resin komposit mikrofiller dan resin-modified glass ionomer cement. Restorasi resin komposit mikrofiller sebanyak 16 sampel dan resin-modified glas ionomer cement sebanyak 16 sampel. Hasil penelitian berupa penetrasi larutan pewarna pada dinding kavitas dan bahan restorasi pada gigi yang telah dipotong secara labiolingual. Sampel dilakukan evaluasi kebocoran mikro menggunakan stereomicroscope $\mathrm{di}$ laboratorium metalurgi jurusan teknik mesin Universitas Andalas.

Hasil penelitian berdasarkan uji statistik tidak ada perbedaan bermakna antara kebocoran mikro pada restorasi resin komposit mikrofiller dan resinmodified glass ionomer cement pada kavitas klas V gigi anterior. Namun dapat diamati bahwa kebocoran pada restorasi resin-modified glass ionomer cement lebih kecil dari resin komposit mikrofiller, walaupun tidak ada perbedaan yang signifikan dari hasil uji statistik.

Secara teori, kebocoran mikro disebabkan oleh banyak faktor. Faktor yang paling utama menyebabkan terjadinya kebocoran mikro adalah adanya penyusutan pada saat polimerisasi (polymerization shrinkage). Penyusutan ini disebabkan oleh berbagai 
hal, salah satunya disebabkan oleh aspek material dari bahan restorasi. Penelitian yang dilakukan Razak AAA et all memperlihatkan rata-rata penyusutan linear dengan bahan pengisi $79 \%$, $65 \%$, dan 50\% komposit prima $\mathrm{APH}$ masing- masing adalah $0.33 \%, 0.35 \%$ dan $0,42 \%$. Dari hasil analisis didapatkan hubungan antara kandungan bahan pengisi dengan penyusutan adalah $r=-0.958$ dengan hasil yang signifikan $(\mathrm{P}<0.01)$. Dari hasil ini, memperlihatkan semakin tinggi kandungan bahan pengisi semakin menurunkan penyusutan polimerisasi. Dalam penelitian ini menggunakan bahan resin komposit mikrofiller dengan muatan bahan pengisi anorganik $60 \%$ volume sedangkan untuk RMGIC dengan muatan $68,6 \%$ volume. Karena kandungan bahan pengisi yang tidak jauh berbeda, perbedaan pengerutan juga tidak signifikan. ${ }^{9}$

Pengerutan akibat polimerisasi dari material resin masih sangat dipertimbangkan sebagai penyebab gagalnya restorasi. Material resin yang terdapat pada bahan restorasi menyebabkan pengerutan yang terjadi pada saat polimerisasi berlangsung. Material resin dari RMGIC sekitar 15$25 \%$, dengan bahan resin yang sedikit maka kemungkinan mengalami pengerutan juga lebih kecil dibandingkan dengan resin komposit mikrofiller yang memiliki material resin yang lebih banyak..$^{10,8,11}$

Penurunan tingkat kebocoran mikro pada restorasi RMGIC kemungkinan juga disebabkan oleh adanya aktivasi polimerisasi secara kimia berupa reaksi asam-basa oleh komponen GIC, sama halnya dengan GIC konvensional. Reaksi ini juga memberikan keuntungan apabila unit curing penyinaran tidak mampu menembus bagian terdalam restorasi, reaksi asam basa ini dapat memberikan efek curing apabila tidak tercapai oleh unit penyinaran. Reaksi asam basa ini tidak menyebabkan penyusutan bahan selama proses polimerisasi, sehingga lebih menguntungkan dan memungkinkan mengalami penyusutan polimerisasi lebih sedikit dibandingkan dengan resin komposit. ${ }^{8,7}$ Reaksi polimerisasi dalam proses selanjutnya dapat berinteraksi dengan lingkungan rongga mulut yang lembab yang dapat menyebabkan serangkaian perubahan fisik pada bahan restorasi berbasis resin. Bahan restorasi berbasis komposit dapat menyerap sejumlah air ketika terpapar lingkungan rongga mulut. Begitu juga dengan bahan restorasi resin-modified glass ionomer 
cement, bahan ini mengalami ekpansi yang cepat ketika terpapar oleh air. Penyerapan air ini akan menyebabkan perubahan dimensi dan perubahan tahanan dari sejumlah material, hal ini dapat memicu terbentuknya celah marginal yang menyebabkan kebocoran. ${ }^{12,9}$

Faktor lain yang menyebabkan terjadinya kebocoran mikro adalah koefisien termal ekspansi. Perubahan dimensi dari suatu substansi dalam menanggapi suatu perbedaan temperatur disebut dengan koefisien termal ekspansi. Material restorasi memiliki perbedaan koefisien termal ekspansi terhadap enamel dan dentin. Nilai koefisien termal ekspansi dentin sekitar $8,3 \times 10^{-6} /{ }^{\circ} \mathrm{C}$ dan email $11,4 \times 10^{-6} /{ }^{\circ} \mathrm{C}$. Resin komposit mikrofiler memiliki nilai koefisien termal ekspansi antara 55-68 x $10^{-6} /{ }^{\circ} \mathrm{C}$, sedangkan RMGIC memiliki nilai koefisien termal ekspansi sebesar $13 \times 10^{-6} /{ }^{\circ} \mathrm{C}$. Hal ini menunjukan bahwa perbedaan koefisien termal ekspansi antara dentin atau enamel terhadap resin komposit mikrofiller lebih besar dibandingkan dengan RMGIC. Perbedaan koefisien termal ekspansi yang tinggi antara gigi dan bahan restorasi dapat menyebabkan perubahan dimensi. Bahan restorasi cenderung memperluas dan berkontraksi terhadap struktur gigi. Ekspansi dan kontraksi tersebut berkembang dan menghasilkan tekanan pada permukaan gigi dan restorasi yang menghasilkan pelepasan ikatan dan pembentukan celah. ${ }^{2,13,14}$

Faktor lain yang menyebabkan terjadinya kebocoran mikro adalah modulus elastisitas. Penelitian secara in vitro memperlihatkan bahwa tekanan permukaan selama setting penyusutan berkaitan jelas dengan tingkat kekakuan dari setting material yang biasa dikenal dengan modulus elastisitas. Sehingga nilai penyusutan yang diberikan material yang paling rigid (material yang memperlihatkan modulus elastisitas yang paling besar) akan menyebabkan stress yang besar juga. Oleh sebab itu, modulus elastisitas juga meningkatkan proses reaksi polimerisasi. Semakin besar modulus elastisitas dan penyusutan polimerisasi, akan menghasilkan tekanan kontraksi yang besar. RMGIC memiliki modulus elastisitas yang sesuai dengan struktur gigi, hal ini dapat menurunkan defek marginal pada restorasi yang dapat mengurangi terjadinya kebocoran mikro. 15,16 


\section{KESIMPULAN}

Dari hasil penelitian mengenai kebocoran mikro pada restorasi resin komposit mikrofiller dengan resinmodified glass ionomer cement pada kavitas klas $\mathrm{V}$ gigi anterior, dapat disimpulkan bahwa tidak terdapat perbedaan yang signifikan antara kebocoran mikro pada restorasi resin komposit mikrofiller dengan resinmodified glass ionomer cement pada kavitas klas $\mathrm{V}$ gigi anterior.

\section{SARAN}

1. Pada penelitian selanjutnya, dapat dilakukan evaluasi kebocoran mikro pada bahan tambal jenis lainnya dengan kavitas yang berbeda.

2. Untuk penelitian selanjutnya disarankan untuk menggunakan bahan restorasi dari produsen yang sama.

3. Hasil dari penelitian ini agar dapat diaplikasikan oleh dokter gigi atau dokter gigi muda untuk mempertimbangkan pemilihan bahan menggunakan jenis bahan restorasi resin komposit mikrofiller dengan resin- modified glass ionomer cement dengan mempertimbangkan kelebihan dan kekurangan masing-masing bahan tersebut.

\section{KEPUSTAKAAN}

1. Baum, phillips, lund. Buku Ajar Ilmu Konservasi Gigi. $3^{\text {rd }}$ rev. transl. Tarigan R, Translator. Jakarta: EGC, 1997.

2. Powers JM, Sakaguchi RL. Craig's Restorative Dental Materials. Elsevier

3. Anusavice. Buku Ajar Ilmu Bahan Kedokteran Gigi. $10^{\text {th }}$ rev. Transl. Budiman JA, Purwoko S, Translator. Jakarta: EGC, 2003.

4. Lokhande N, Padamai A, Rathore V. Effectiveness Of Flowable Resin Composite in Reducing Mickroleakage. J Inter Oral Health. 2014 Jun;6(3):111114.

5. Cimello DT, Chinelati MA, Ramos RP, Palma RG. In Vitro Evaluation of Microleakage of a Flowable Composite in Class V Restorations. Braz Dent J. 2002;13(3)

6. Nicholson JW. The Chemistry of Medical and Dental Materials. $1^{\text {st }}$ rev. ed. Connor JA, Editor. UK: The Loyal Society of Chemistry, 2002.

7. Bonsor SJ, Pearson GJ. A Clinical Guide to Applied Dental Materials. $1^{\text {st }}$ rev. ed. British: Elsevier, 2013.

8. Van N. Introduction To Dental Materials. USA: Elsevier; 2007.

9. Sing M, Palekar A. Polymerization Shrinkage of Composite Resin. NJDSR. 2014 Jan 1;2(1):58-61.

10. Mousavinasab SM, Khosravi K, Tayebghasaemi N. Microleakage Assesment of Class V Composite Restorations Rebonded with Three Different Methods. Dent Res J. 2008;5(1):21-26.

11. Graham JM, Hume WR. Preservation and restoration of tooth structure. Mosby; 1998.

12. McCabe JF, Walls AWG. Apllied Dental Materials. 9th rev. ed. Oxford: Blackwell, 2008.

13. Majeed, Abdul. An Invitro Study of Microleakage and Surface Microhardeness of Nanocomposite Restorative Materials. A minithesis submitted in partial fullfilment of requirements for degree of Master of Science in Restorative Dentistry. Faculty 
of Dentistry of thr Western Cape; 2005.

14. Soratur SH. Essensial of Dental Materials.1st rev. ed. New Delhi: Jaypee Brothers Medical,2002.

15. Giachetti L, Russo DS, Bambi C, et all. A Review of Polymerization Shrinkage Stress : Current Techniques for Posterior Direct Resin Restorative. The Journal of Contemporary Dental practice. 2006 Sep 1;7(4):1-14.

16. Karthick K, Kailasam S, Priya, et all.mPolymeryzation Shrinkage of Composite. JIADS. 2011 Apr-Jun;2(2):3236. 